\title{
Comparing chromosome damage induced by mobile telephony radiation and a high caffeine dose: Effect of combination and exposure duration
}

\author{
Dimitris J. Panagopoulos ${ }^{1,2,3}$ \\ ${ }^{1}$ National Center for Scientific Research "Demokritos", Athens, Greece \\ ${ }^{2}$ Choremeion Research Laboratory, Medical School, National and Kapodistrian University of Athens, Greece \\ ${ }^{3}$ EMF-Biophysics Research Laboratory, Athens, Greece
}

\begin{abstract}
I recently reported induction of chromatid-type aberrations in human peripheral blood lymphocytes after a single 15 min exposure to Universal Mobile Telecommunications System (UMTS) Mobile Telephony (MT) Electromagnetic Field (EMF) from a mobile phone. Lymphocytes from six healthy subjects were stimulated for mitosis, and exposed during the $\mathrm{G}_{2} / \mathrm{M}$ phase at $1 \mathrm{~cm}$ distance from the handset during an active phone call in "talk" mode. The same type of cells from the same subjects treated with a high caffeine dose $(\sim 290$ times above the permissible single dose for an adult human) exhibited the same type of aberrations in a little smaller but comparable degree. The combination of this caffeine dose and the 15 min MT EMF exposure increased dramatically the number of aberrations in all subjects. The combined effect increased almost linearly with increasing duration of exposure to the MT EMF. Thus, MT EMF exposure $\sim 136$ times below the official limit (ICNIRP 2020) exerts a genotoxic action even greater than that of a caffeine dose $\sim 290$ times above the corresponding limit. Therefore, with a reasonable approximation, the limit for MT EMFs should be lowered by at least $\sim 4 \times 10^{4}$ times $(136 \times 290)$ for short-term exposures, and $\sim 4 \times 10^{6}$ times for long-term exposures.
\end{abstract}

Key words: Electromagnetic fields - Mobile phone radiation - Caffeine - Human lymphocytes - Chromatid aberrations - DNA damage

\section{Introduction}

The scientific community and the general public are increasingly concerned about the adverse effects of man-made Electromagnetic Fields (EMFs) especially those employed in modern microwave telecommunications including Mobile Telephony (MT). All microwave telecommunications EMFs always combine Radio-Frequency (RF)/microwave carrier waves (on the order of $\mathrm{GHz}$ ) with Extremely Low Frequency (ELF) (up to $3000 \mathrm{~Hz}$ ) pulsing and modulation in order to

Correspondence to: Dimitris Panagopoulos, Laboratory of Health Physics, Radiobiology and Cytogenetics, Institute of Nuclear and Radiological Sciences and Technology, Energy and Safety, National Center for Scientific Research "Demokritos", 60037 Ag. Paraskevi, Athens, Greece

E-mail: dpanagop@biol.uoa.gr increase the amount and speed of transmitted information (speech, text, images, video, Internet, etc.) (Panagopoulos 2011, 2017, 2019a, 2019b). Both RF and ELF EMFs have been classified by the International Agency for Research on Cancer (IARC) as possibly carcinogenic to humans (group 2B) under the weight of the accumulating scientific evidence (IARC 2002, 2013; Baan et al. 2011). Based on additional scientific evidence after the 2011 IARC classification for RF EMFs, several studies have suggested that RF (including MT) EMFs should be re-evaluated and classified as probably carcinogenic (group 2A) or carcinogenic (group 1) to humans (Hardell et al. 2013; Carlberg and Hardell 2017; Hardell 2017, 2019; Miller et al. 2018; Panagopoulos 2019b; Hardell and Carlberg 2020; Hardell and Nyberg 2020). Moreover it is shown that the majority of studies performed with simulated/invariable microwave EMFs emitted by generators (following IARC's guidelines) grossly underestimate the biological activity of 
real-life highly variable exposures by commercially available devices (Panagopoulos et al. 2015a; Panagopoulos 2017, 2019a, 2019b; Kostoff et al. 2020).

Universal Mobile Telecommunications System (UMTS) or third generation (3G) MT EMFs/radiation emitted by commercially available mobile phone handsets and base antennas is still the most usual type of modern MT radiation exposing daily billions of mobile phone users and non-users throughout the world. While 2G Global System for Mobile telecommunications (GSM) is still in use and $4 \mathrm{G}$ - a combination of $3 \mathrm{G}$ MT and a different microwave radiation with carrier frequency up to $2.6 \mathrm{GHz}$ for broadband Internet access - is the newest widely in use type, telecommunication industry has already begun the installation of the 5G MT system. This involves an even higher carrier frequency (up to $100 \mathrm{GHz}$ ) in order to be able to transmit higher amounts of data per second, and a much denser network of base antennas of possibly increased power in order to compensate the energy scattering loss due to the higher carrier frequency (Sauter 2011; Singh et al. 2017; Hardell and Carlberg 2020; Hardell and Nyberg 2020; Kostoff et al. 2020). A part of the scientific community has expressed strong objections to $5 \mathrm{G}$ installation with concerns of highly increased health risk (McClelland and Jaboin 2018; Miller et al. 2018, 2019; Pall 2018; Panagopoulos 2019a, 2019b; Hardell and Carlberg 2020; Hardell and Nyberg 2020; Kostoff et al. 2020).

Numerous studies have already reported genotoxic effects of RF/microwave and especially MT EMFs on a variety of organisms and cell/tissue types (Panagopoulos 2019b). A recent study of the USA National Toxicology Program (NTP) found that rats exposed for 2 years, $9 \mathrm{~h}$ per day, to a simulated near-field of a mobile phone antenna emitting $2 \mathrm{G}$ or $3 \mathrm{G}$ MT EMFs developed brain and heart cancer. Moreover the study found significantly increased DNA damage (strand breaks) in the brains of exposed animals (NTP 2018; Melnick 2019; Smith-Roe et al. 2020), confirming the fact that DNA damage is intimately related with epigenetic cancer. In a similar Italian life-span study, rats were exposed to a simulated GSM 1800 far-field, and were also found to get heart schwannomas and brain glial tumors in agreement with the NTP study (Falcioni et al. 2018). A study that compared the bioactivity between $2 \mathrm{G}$ and $3 \mathrm{G}$ MT EMFs/radiation emitted by an active mobile phone, found both types of MT EMFs inducing DNA damage and histological changes on the developing liver of chick embryos, with 3G (UMTS) being even more genotoxic/bioactive than 2G (GSM) (D'Silva et al. 2017).

Human peripheral blood lymphocytes - naturally arrested in $G_{0}$ phase and usually stimulated for mitosis (M) - are a well-known model for the assessment of genotoxicity of environmental agents such as ionizing radiation, chemicals, smoking, pharmaceuticals, EMFs, etc. (IAEA 2011). Before my previous experimental report (Panagopoulos 2019a) several other studies had already been conducted to search the effects of MT EMFs on human peripheral blood lymphocytes in vitro (Zeni et al. 2003, 2012; Baohong et al. 2005, 2007; Belyaev et al. 2005, 2009; Markova et al. 2005; Stronati et al. 2006; Manti et al. 2008; Schwarz et al. 2008; ElAbd and Eltoweissy 2012). The majority of these studies have found genotoxic effects induced by the MT EMFs alone or in combination with other genotoxic agents (see Panagopoulos 2019a). One of these studies found DNA strand breaks and chromosomal aberrations induced by UMTS-like MT EMF at degrees increasing with longer exposure duration. The effects were attributed to oxidative stress induced by the EMF exposure (El-Abd and Eltoweissy 2012). Stronati et al. (2006) did not find any DNA or chromosomal damage induced by a GSM-like exposure during the $\mathrm{G}_{0}$ phase. All of these studies employed simulated/invariant MT EMFs produced by generators or test phones which as already mentioned are significantly less bioactive than real-life MT EMFs (Panagopoulos et al. 2015a; Panagopoulos 2017, 2019b; Kostoff et al. 2020). Two laboratory studies were found that employed real-life MT EMF exposure of human lymphocytes by commercially available mobile phones: In the older one (Ji et al. 2004), volunteers were exposed in vivo by talking on their GSM (2G) mobile phones for $4 \mathrm{~h}$. After the exposure, DNA damage in their blood samples was significantly increased compared to their blood samples before the exposure. In the newer study (Danese et al. 2017) blood samples were exposed in vitro for $30 \mathrm{~min}$ to a GSM (2G) real signal emitted by an activated mobile phone and no significant effect on DNA double strand breaks was reported. While the authors of this study used a $3 \mathrm{G}$ mobile phone for the exposures, they did not test the $3 \mathrm{G}$ signal but the much older (and less bioactive) 2G signal. The authors do not report whether they exposed during "talk" mode (modulated/speaking emission) or during "listening" or other mode. No EMF-measurements were reported, and they applied an assay (the foci method) which does not detect other types of DNA damage apart from double strand breaks, without showing any foci pictures from exposed and control samples. Most importantly, the blood samples were exposed during their resting $\mathrm{G}_{0}$ phase (like in Stronati et al. 2006) while it is known that proliferating cells are much more vulnerable than resting cells of the same kind with most sensitive phases of the cell division cycle being M, and $G_{2}$ (Nias 1998; Terzoudi et al. 2011). Certainly, in vivo studies inevitably employ exposures during $\mathrm{G}_{0}$ since lymphocytes are normally in this phase. In such a case the duration of exposure has to be longer, like in Ji et al. (2004).

Two studies examined peripheral blood lymphocytes from people residing in the vicinity of MT base stations and thus exposed in vivo to real-life MT EMFs/radiation emitted by the base antennas. Both studies Gulati et al. (2016) and Zothansiama et al. (2017) found significantly increased genetic damage compared to control groups residing more 
than 800 or $300 \mathrm{~m}$, respectively, away from the antennas/ cell towers.

A most sensitive assay to record sensitivity of human peripheral blood lymphocytes to environmental stressors is the $\mathrm{G}_{2}$ assay. This allows observation at metaphase of unrepaired DNA damage induced during $G_{2}$ or early $M$-phase and converted into chromatid-type aberrations in cells activated for mitosis (Terzoudi and Pantelias 2006; Pantelias and Terzoudi 2010, 2011; Terzoudi et al. 2011; Panagopoulos 2019a).

The reason for the increased sensitivity of the $G_{2}$ phase of the mitotic cycle is related with the existence of a checkpoint. Checkpoints in biological systems exist at the most sensitive stages of metabolic procedures and are cellular damage detectors and repair activators. This checkpoint during the $G_{2}$ phase identifies cellular damage and either activates repair mechanisms, or drives the cell to apoptosis when the damage is not reparable, in order to prevent proliferation of cells with genetic damage (Mendelsohn et al. 1981; Pantelias and Terzoudi 2011). Caffeine in high doses is considered to be a blocker/abrogator of the $\mathrm{G}_{2}$ checkpoint. Moreover, it is well-known that addition of caffeine in cell cultures results in DNA damage and chromatid aberrations (Kuhlmann et al. 1968; Pincheira and Lopez-Saez 1991; Hatzi et al. 2015). Caffeine was previously classified by IARC as possibly carcinogenic to humans (IARC 1991), but was recently reevaluated as non-carcinogenic (IARC 2016).

I recently reported that a 15 min single exposure of human peripheral blood lymphocytes to UMTS EMF emitted by a commercially available mobile ("smart") phone during an active phone call in "talk" mode at $1 \mathrm{~cm}$ distance from the blood samples induced chromatid breaks and gaps at highly significant percentages (up to $+275 \%$ ) compared to the sham-exposed (control) samples in all six healthy subjects tested. The lymphocytes were stimulated to enter the mitotic cycle. Those exposed during the $G_{2}$ or early $\mathrm{M}$ phase were arrested at metaphase by colcemid treatment and observed by light microscopy (Panagopoulos 2019a).

The purpose of the present study was to compare the genotoxic activity of UMTS (3G) MT EMFs/radiation on human cells described in my previous report (Panagopoulos 2019a), with that of a high caffeine dose, and test the genotoxicity of the combination of the two stressors. No other study has up to today compared the genotoxicity, or investigated the combined effect of caffeine and MT EMF exposure, and therefore the present study is novel.

\section{Materials and Methods}

\section{Blood culture and separation into groups}

After obtaining consent, blood samples were collected from six healthy non-smoker adult donors (one sample from one donor in each experiment) in heparinized glass tubes, for analysis of chromosomal sensitivity to mobile phone exposure. The donors/subjects were both males and females, 28-42 years old, with "moderate" mobile phone use (no more than $30 \mathrm{~min}$ total daily conversation on their mobile phones), and no reported history of major illnesses or any regular medication. Apart from this, no specific differences between the subjects were searched, since each subject had its own control sample. Whole blood samples were cultured in RPMI 1640 medium (Biochrom AG, Germany) containing 10\% fetal bovine serum (FBS), $1 \%$ L-glutamine $(2 \mathrm{mM}$ ), and $1 \%$ antibiotics (penicillin: $100 \mathrm{U} / \mathrm{ml}$; streptomycin: $100 \mu \mathrm{g} / \mathrm{ml}$ ). Phytohaemagglutinin (PHA) $2 \%$ of the final medium volume (dissolved in water at a concentration of $0.24 \mathrm{mg} / \mathrm{ml}$ ) was added to stimulate the lymphocytes (normally arrested in the $\mathrm{G}_{0}$ phase) to enter the mitotic cycle (Panagopoulos 2019a).

For each subject, a single culture was prepared in a $200 \mathrm{ml}$ flask (which was later divided into individual samples/groups) to ensure identical culture conditions and treatment for all individual samples/groups in each experiment. The culture was incubated for $72 \mathrm{~h}$, at $37^{\circ} \mathrm{C}$ in a humidified incubator with an atmospheric content of 5\% $\mathrm{CO}_{2}$ and $95 \%$ air.

After $72 \mathrm{~h}$ of incubation the single blood culture was subdivided into individual samples/groups in identical $30 \mathrm{ml}$ rectangular plastic flasks. [Each individual group contained: $0.5 \mathrm{ml}$ blood, $5 \mathrm{ml}$ culture medium, $100 \mu \mathrm{l}$ PHA]. One sample would be exposed to the UMTS EMF for $15 \mathrm{~min}$, and another one would be sham-exposed as previously described (Panagopoulos 2019a). Two additional samples/groups were treated with caffeine for all six individuals. One of them would be exposed for $15 \mathrm{~min}$ to the UMTS EMF, and the other sham-exposed. In three (out of the six) individuals (subjects No. 4, 5, 6) two more additional samples/groups were treated with caffeine, one exposed for $5 \mathrm{~min}$ and the other for 25 min to the UMTS EMF, in order to study the effect of exposure duration $(5,15,25 \mathrm{~min})$ to the UMTS EMF combined with the caffeine dose. Therefore the number of individual samples/groups concerning the present experiments were either 4 (one sham-exposed/control, one UMTS 15 min-exposed, one caffeine-treated alone and sham-exposed to the EMF, and one treated with caffeine and UMTS EMF for $15 \mathrm{~min}$ ), or 6 (same groups as described plus the two additional caffeine-treated groups one exposed $5 \mathrm{~min}$ and the other $25 \mathrm{~min}$ to the UMTS EMF). Right after the separation of the initial culture into individual groups/ samples and the addition of caffeine in the specific samples as described above, the blood samples were either exposed to the UMTS MT EMF in another room of the laboratory (called "exposure room"), or sham-exposed (simply transferred for $15 \mathrm{~min}$ to the exposure room). Preliminary experiments had shown that there was no notable difference between groups sham-exposed for $15 \mathrm{~min}$ and groups sham- 
exposed for 5 or $25 \mathrm{~min}$. For this reason all sham-exposures took place for $15 \mathrm{~min}$.

\section{EMF exposure system and Caffeine dose evaluation}

Exposures were performed by a UMTS (3G) commercially available "smart" mobile phone handset in order to test the effects of real-life exposures experienced daily by billions of MT users around the world. For description of the parameters of the UMTS EMF (modulation, pulsing, etc.) see Panagopoulos (2019a). SAR value of the handset for the human head according to the manufacturer is $0.66 \mathrm{~W} / \mathrm{kg}$. The Internet connection (data), Wi-Fi, and Bluetooth antennas of the "smart" phone were disabled like in Panagopoulos (2019a).

The RF radiation intensity, emitted by the handset during the exposures was measured at $1 \mathrm{~cm}$ distance from the handset by a Cornet ED85EXpluss RF meter (Cornet Microsystems Inc., USA), and a Spectran HF-4040V3 spectrum analyzer (Aaronia AG, Germany), both with a near-field antenna. The ELF electric and magnetic field intensities (ELF-E and ELF-B) emitted by the handset were measured at $1 \mathrm{~cm}$ distance by a Spectran NF-1010E (Aaronia AG, Germany) spectrum analyzer. Representative average peak power density (from five representative peak instant measurements excluding background) in the RF band \pm Standard Deviation (SD) was $92 \pm 27 \mu \mathrm{W} / \mathrm{cm}^{2}$. Averaged power density over six min (in compliance with the International Commission on Non-Ionizing Radiation Protection-ICNIRP limits) was $29 \pm 14 \mu \mathrm{W} / \mathrm{cm}^{2}$, which is $\sim 34$ times below the corresponding ICNIRP (1998) general public limit of $1000 \mu \mathrm{W} / \mathrm{cm}^{2}$ for the frequency of $2-6 \mathrm{GHz}$, and $\sim 136$ times below the latest ICNIRP (2020) corresponding limit which is raised (!) to $4000 \mu \mathrm{W} / \mathrm{cm}^{2}$. The carrier frequency was variable 1920-1960 MHz during the exposures. Representative average ELF-E and ELF-B (from five representative instant measurements excluding background) $\pm \mathrm{SD}$ at $100 \mathrm{~Hz}$ was $12 \pm 4.2 \mathrm{~V} / \mathrm{m}$, and $0.9 \pm 0.4 \mathrm{mG}$, respectively. Corresponding average ELF-E and ELF-B (from five instant measurements excluding background) $\pm \mathrm{SD}$ at $1500 \mathrm{~Hz}$ was $8 \pm 4.6 \mathrm{~V} / \mathrm{m}$, and $0.06 \pm 0.02 \mathrm{mG}$, respectively. All measurements were carried out separately from the exposures in order to have the measuring devices at the same location with the samples during the exposures.

In each individual sample/group treated with caffeine, $200 \mu \mathrm{l}$ caffeine solution was added (containing $0.2 \mathrm{~g}$ caffeine per $10 \mathrm{ml}$ PBS). In other words, each individual caffeinetreated sample with total volume $5.8 \mathrm{ml}(5 \mathrm{ml}$ culture medium, $0.5 \mathrm{ml}$ blood, $100 \mu \mathrm{PHA}$, and $200 \mu \mathrm{l}$ caffeine solution) contained $4 \mathrm{mg}$ caffeine. Thus the final caffeine concentration was $\sim 3.4 \mathrm{mM}$. This caffeine dose is considered to abrogate the $G_{2}$ checkpoint (Pantelias and Terzoudi 2011; Hatzi et al. 2015). Thus, to $0.5 \mathrm{ml}$ blood of each sample ( $8.6 \%$ of the sample volume) correspond $\sim 0.34 \mathrm{mg}$ caffeine $(8.6 \%$ of the caffeine in the sample), and to $\sim 51$ whole blood contained in a $70 \mathrm{~kg}$ adult human body correspond $\sim 3.4 \mathrm{~g}$ caffeine. In the case of drinking coffee, caffeine does not go directly into the blood since first passes through the peptic system and distributed to all tissues. It is estimated that from an initial amount A g of caffeine administered by coffee drinking, about $\sim \mathrm{A} / 17$ is dissolved into the blood (Cook et al. 1996; Higdon and Frei 2006). Therefore, the amount of caffeine administered directly in each caffeine-treated blood sample corresponds to approximately $3.4 \mathrm{~g} \times 17=57.8 \mathrm{~g}$ caffeine taken by coffee by an adult $70 \mathrm{~kg}$ individual. The permitted single caffeine dose for a $70 \mathrm{~kg}$ adult is $0.2 \mathrm{~g}$, which is 290 times smaller than the $57.8 \mathrm{~g}$ which correspond to the dose used in the experiments (EFSA 2015). Thus, the caffeine dose used in the experiments was $\sim 290$ times higher than the permitted single dose for an adult individual of $70 \mathrm{~kg}$ body weight. This is an important result for the comparison between caffeine and MT EMF exposures.

\section{EMF exposure procedure}

Two blood samples from each subject (one with caffeine and one without) were simultaneously exposed within the $30 \mathrm{ml}$ flasks by the UMTS (3G) mobile phone handset during an active phone-call ("talk" signal) for $15 \mathrm{~min}$ at $1 \mathrm{~cm}$ distance from the proximal flask wall. This took place in the exposure room so that the controls (in the culture room) would not be exposed. Two additional blood samples of individuals No. 4, 5, 6 treated with caffeine were simultaneously with the others exposed for 5 and $25 \mathrm{~min}$ to the UMTS EMF in order to study the effect of exposure duration to the UMTS EMF in combination with the caffeine dose (each sample that its exposure was completed was taken back to the culture room while the other samples continued to be exposed). After all the exposed samples were back in the culture room, the corresponding control (sham-exposed) samples were also transferred in the exposure room for $15 \mathrm{~min}$ at the same location as the exposed samples, without being exposed to the MT EMF. This was done because the background ELF-E and ELF-B and the light conditions in the two rooms were different.

The temperature in the two rooms was the same during the procedures/exposures and was kept at $22 \pm 1^{\circ} \mathrm{C}$. In both rooms the RF background was below $0.01 \mu \mathrm{W} / \mathrm{cm}^{2}$. In the exposure room the ELF-E background was $\sim 2 \mathrm{~V} / \mathrm{m}$, and the ELF-B background $\sim 0.3 \mathrm{mG}(0.03 \mu \mathrm{T})$. In the culture room the corresponding ELF background fields were higher $(\mathrm{E} \sim 10 \mathrm{~V} / \mathrm{m}, \mathrm{B} \sim 1 \mathrm{mG})$ due to electrical devices, such as the culture chamber and the hood, existing in all biological laboratories. Temperature increases within the blood samples during the longest 25 min exposures did not exceed $0.2^{\circ} \mathrm{C}$ as measured within an identical culture 
and flask by a HANNA CheckTemp 1 calibrated electronic thermometer (USA).

\section{Metaphase arrest, fixation and observation}

After exposures/sham-exposures were completed $(\sim 30$ $60 \mathrm{~min}$ after the beginning of the exposure procedure) and all the exposed and sham-exposed samples were returned back to the culture room, all individual groups/samples were treated with colcemid ( $50 \mu$ ladded to each sample) for $60 \mathrm{~min}$, to arrest dividing cells at metaphase. Colcemid prohibits dividing cells to proceed from metaphase to anaphase by prohibiting the formation of attractus. Keeping the cells in metaphase makes their condensed chromosomes clearly observable by light microscopy for possible aberrations. The duration of colcemid treatment $(60 \mathrm{~min})$ right after the termination of exposure/sham-exposure plus the exposure/ sham-exposure time (1.5-2 $\mathrm{h}$ in total) determines in which phases of the cell-division cycle the arrested in metaphase lymphocytes were exposed. In this case, the $1.5-2 \mathrm{~h}$ period determines that the cells collected for observation were at the mid-late $G_{2}$ or early $M$ (prophase) stages during the exposure/sham-exposure. It also determines the duration of caffeine-treatment of the specific samples.

Cells were then collected by centrifugation, treated for 10 min with hypotonic $\mathrm{KCl}$ solution $75 \mathrm{mM}$ (Sigma-Aldrich, USA), fixed in methanol: glacial acetic acid (3:1 v/v), and stained for 10 min with 5\% Giemsa solution (Merck, Germany) to be observed by light microscopy. Light microscopy was coupled with an image analysis system (Ikaros MetaSystems, Germany) to facilitate scoring.

Chromosomal damage was evaluated by the number of chromatid gaps (achromatic lesions) and chromatid breaks (terminal deletions) in cells at metaphase. For each of the 4 or
6 samples of each subject (described above) 400 metaphases identically processed from 4 different slides (100 cells from each slide), were blindly scored for gaps and breaks. Mean values of total number of aberrations (gaps and breaks) per cell and SD in all samples were calculated for each individual. Gaps were scored only when extended across the full chromatid width. An aberration was considered as "break" when the gap width was equal to or greater than the chromatid width.

\section{Statistical analysis}

Results were statistically analysed by application of the Student's $t$-test for unequal variances (Microsoft Excel program) between exposed and control groups for each individual. The $p$-values $<0.05$ for the probability that differences between groups are due to random variations were accepted as statistically significant.

\section{Results}

Results from experiments with the six healthy subjects (No. 1-6) with 1600 metaphases scored from each one (400 exposed to UMTS alone, 400 to caffeine alone, 400 to combination of UMTS plus caffeine, and 400 from control/ sham-exposed blood samples) are listed in Table 1 and represented graphically in Figure 1. A single 15-min exposure by the UMTS mobile phone during a phone call in "talk" mode at $1 \mathrm{~cm}$ distance, increased the total number of chromosomal aberrations (chromatid gaps and breaks) by $100-275 \%$ in regards to the sham-exposed/control samples, while caffeine alone (and sham-exposure to the EMF) increased the same number by $89-250 \%$. In four out of the six subjects the number

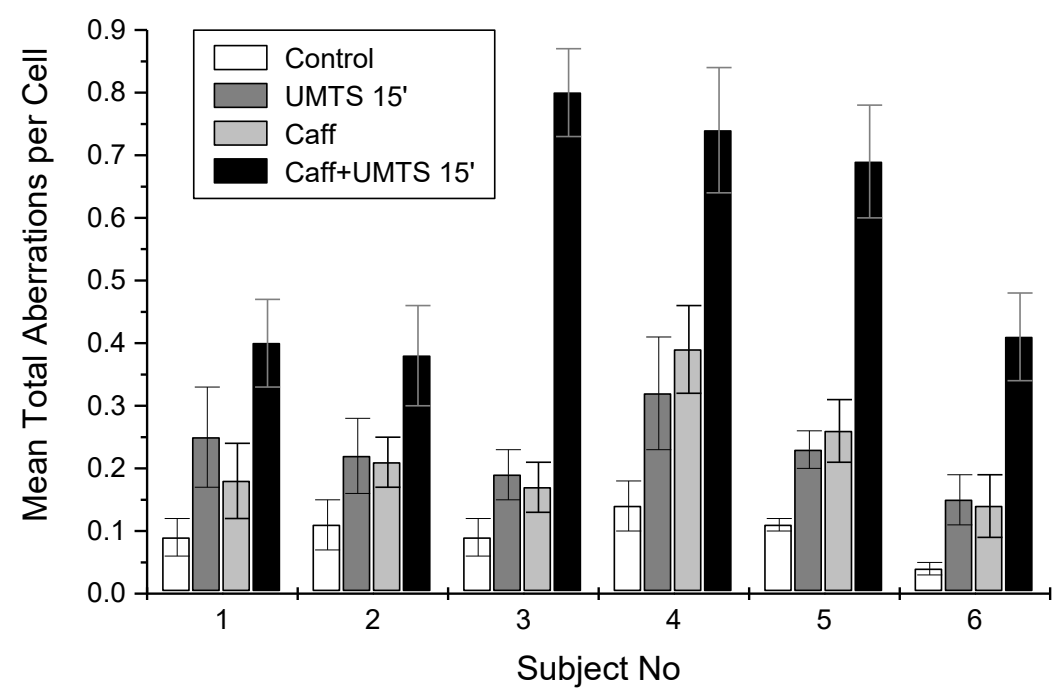

Figure 1. Mean total number of aberrations (gaps and breaks) per cell in 400 cells (peripheral blood lymphocytes) of each group: Control, UMTS 15' (exposed to UMTS for $15 \mathrm{~min}$ ), Caff (caffeinetreated), and Caff+UMTS 15' (exposed to combination of caffeine and UMTS for $15 \mathrm{~min}$ ), for each one of the six subjects (No. 1-6). Data are mean \pm SD. 
Table 1. Chromatid-type aberrations in human lymphocytes induced by caffeine or/and UMTS MT EMF 15 min exposure

\begin{tabular}{|c|c|c|c|c|c|c|c|c|c|}
\hline $\begin{array}{l}\text { Subject No. } \\
\text { (age, sex) }\end{array}$ & $\begin{array}{l}\text { Groups } \\
\text { (Samples) }\end{array}$ & $\begin{array}{l}\text { Gaps in } \\
400 \text { cells }\end{array}$ & $\begin{array}{l}\text { Breaks in } \\
400 \text { cells }\end{array}$ & $\begin{array}{l}\text { Total Aberr. } \\
\text { in } 400 \text { cells }\end{array}$ & $\begin{array}{l}\text { Mean Total Aberr. } \\
\text { per cell } \pm \text { SD }\end{array}$ & $\begin{array}{c}\text { Deviation from } \\
\text { Control (\%) }\end{array}$ & $p$-value & $\begin{array}{l}\text { Deviation from } \\
\text { Caff }(\%)\end{array}$ & $p$-value \\
\hline \multirow{4}{*}{$\begin{array}{c}1 \\
(42, \text { Male })\end{array}$} & Control & 30 & 5 & 35 & $0.09 \pm 0.03$ & & & \multirow{3}{*}{+39} & \multirow{3}{*}{$>0.05$} \\
\hline & UMTS & 84 & 17 & 101 & $0.25 \pm 0.08$ & +178 & $<0.02$ & & \\
\hline & Caff & 50 & 23 & 73 & $0.18 \pm 0.06$ & +100 & $<0.04$ & & \\
\hline & Caff+UMTS & 110 & 51 & 161 & $0.40 \pm 0.07$ & +344 & $<0.01$ & +122 & $<0.01$ \\
\hline \multirow{4}{*}{$\begin{array}{c}2 \\
(33, \text { Female) }\end{array}$} & Control & 37 & 7 & 44 & $0.11 \pm 0.04$ & & & \multirow{3}{*}{+5} & \multirow{3}{*}{$>0.05$} \\
\hline & UMTS & 70 & 19 & 89 & $0.22 \pm 0.06$ & +100 & $<0.03$ & & \\
\hline & Caff & 63 & 22 & 85 & $0.21 \pm 0.04$ & +91 & $<0.02$ & & \\
\hline & Caff+UMTS & 106 & 46 & 152 & $0.38 \pm 0.08$ & +245 & $<0.01$ & +81 & $<0.03$ \\
\hline \multirow{4}{*}{$\begin{array}{c}3 \\
(28, \text { Male })\end{array}$} & Control & 28 & 9 & 37 & $0.09 \pm 0.03$ & & & \multirow{4}{*}{+12} & \multirow{4}{*}{$\begin{array}{l}>0.05 \\
<0.01\end{array}$} \\
\hline & UMTS & 63 & 15 & 78 & $0.19 \pm 0.04$ & +111 & $<0.02$ & & \\
\hline & Caff & 50 & 18 & 68 & $0.17 \pm 0.04$ & +89 & $<0.03$ & & \\
\hline & Caff+UMTS & 160 & 162 & 322 & $0.80 \pm 0.07$ & +789 & $<0.01$ & & \\
\hline \multirow{4}{*}{$\begin{array}{c}4 \\
(40, \text { Male })\end{array}$} & Control & 43 & 15 & 58 & $0.14 \pm 0.04$ & & & \multirow{3}{*}{-18} & \multirow{3}{*}{$>0.05$} \\
\hline & UMTS & 102 & 26 & 128 & $0.32 \pm 0.09$ & +129 & $<0.03$ & & \\
\hline & Caff & 97 & 61 & 158 & $0.39 \pm 0.07$ & +179 & $<0.01$ & & \\
\hline & Caff+UMTS & 190 & 106 & 296 & $0.74 \pm 0.10$ & +429 & $<0.01$ & +90 & $<0.01$ \\
\hline \multirow{4}{*}{$\begin{array}{c}5 \\
(35, \text { Female) }\end{array}$} & Control & 42 & 2 & 44 & $0.11 \pm 0.01$ & & & \multirow{3}{*}{-12} & \multirow{3}{*}{$>0.05$} \\
\hline & UMTS & 82 & 12 & 94 & $0.23 \pm 0.03$ & +109 & $<0.01$ & & \\
\hline & Caff & 70 & 34 & 104 & $0.26 \pm 0.05$ & +136 & $<0.02$ & & \\
\hline & Caff+UMTS & 217 & 59 & 276 & $0.69 \pm 0.09$ & +527 & $<0.01$ & +165 & $<0.01$ \\
\hline \multirow{4}{*}{$\begin{array}{c}6 \\
(30, \text { Male })\end{array}$} & Control & 15 & 2 & 17 & $0.04 \pm 0.01$ & & & \multirow{3}{*}{+7} & \multirow{3}{*}{$>0.05$} \\
\hline & UMTS & 56 & 5 & 61 & $0.15 \pm 0.04$ & +275 & $<0.01$ & & \\
\hline & Caff & 47 & 8 & 55 & $0.14 \pm 0.05$ & +250 & $<0.03$ & & \\
\hline & Caff+UMTS & 124 & 39 & 163 & $0.41 \pm 0.07$ & +925 & $<0.01$ & +193 & $<0.01$ \\
\hline
\end{tabular}

Aberr.: aberrations; Caff: caffeine.

of aberrations induced by UMTS exposure was higher than the number of aberrations induced by caffeine. The combination of caffeine and the 15 min UMTS exposure increased dramatically the corresponding number of induced aberrations by $245-925 \%$ compared to the controls (Table 1, Fig. 1 ). In all subjects, all UMTS-exposed samples (with or without caffeine) and caffeine treated samples differed significantly from the corresponding control/sham-exposed samples $(p<0.04)$ (Table 1). In contrast, in all subjects the UMTS alone-treated samples did not differ significantly from the caffeine alonetreated samples $(p>0.05)$ (Table 1$)$. Thus, while the effect of each stressor was very intense on the human lymphocytes, the effects of the UMTS 15 min exposure alone and the high caffeine dose alone were comparable between them.

In Figure 2A a metaphase of a control blood sample is shown from subject No. 5 (female). This is a representative picture of a metaphase from a control sample/group with all 46 chromosomes intact. Figure 2B shows a metaphase of a blood sample of the same subject, exposed to caffeine only (and sham-exposed to the UMTS EMF), with one chromatid achromatic lesion - gap (g). Figure $2 \mathrm{C}$ shows a metaphase of a blood sample of the same subject exposed to UMTS MT EMF (15 min) with one chromatid terminal deletion - break (b) with displaced fragment (f). Figure 2D shows a metaphase of a blood sample of the same subject (No. 5), exposed to the combination of caffeine and 15 min UMTS MT EMF with two chromatid breaks (b), and one chromatid gap (g).

Each subject exhibited a different sensitivity to each stressor (caffeine or MT EMF exposure). The differential sensitivity was also recorded in the control blood samples due to genetic and environmental factors. The mean number of total aberrations per cell between the six different healthy individuals varied in the control samples from 0.04 to 0.14 , in the UMTS-exposed samples from 0.15 to 0.32 , in caffeine alone-treated samples from 0.14 to 0.39 , and in the samples exposed to the combination of UMTS plus caffeine from 0.38 to 0.80 . In some cases, subjects with fewer aberrations in their control samples exhibited higher sensitivity to the MT EMF exposure, while this was not observed with caffeine (Table 1).

The MT EMF exposure or the high caffeine dose alone, induced mainly gaps, but also breaks in smaller percentages. The number of gaps induced by the UMTS exposure was 4-7 times greater than the corresponding number of induced breaks in all subjects, while the number of gaps induced by caffeine-alone was 2-6 times greater than the correspond- 
A

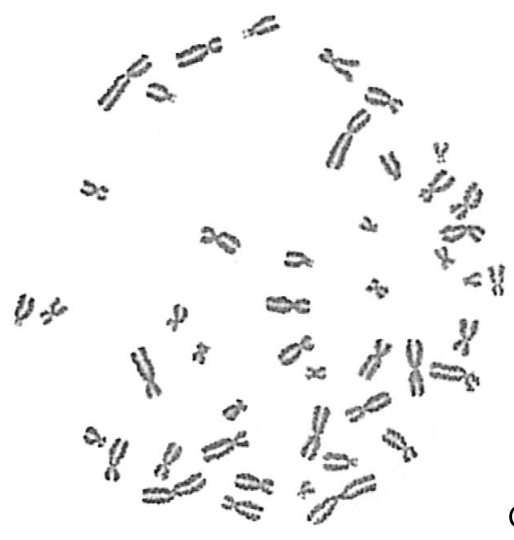

Control

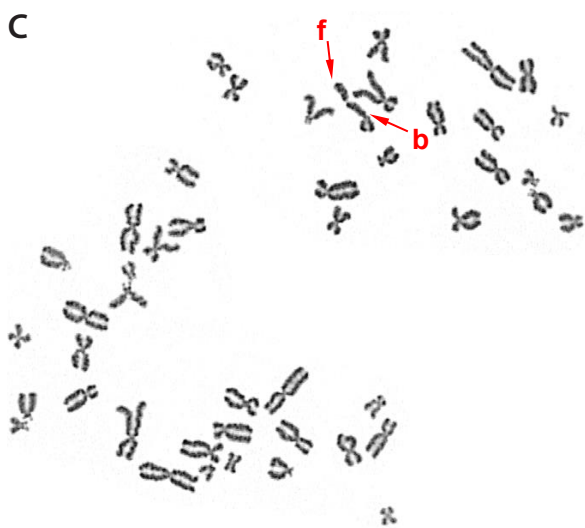

B

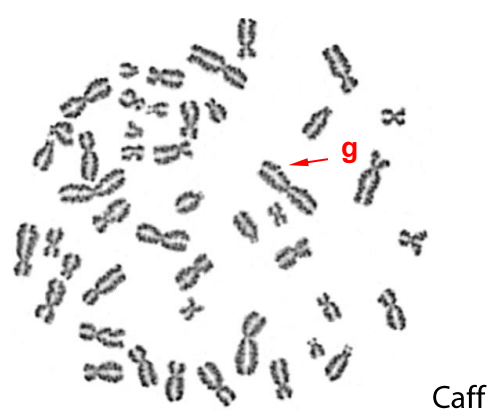

D

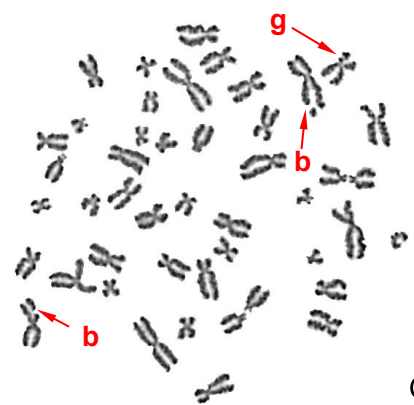

Caff+UMTS

Figure 2. A. Metaphase of Control blood sample from subject No. 5 (female). All 46 chromosomes are intact. B. Metaphase of caffeinetreated blood sample from the same subject with 1 achromatic lesion - gap (g). C. Metaphase of exposed blood sample to UMTS MT EMF for $15 \mathrm{~min}$, from the same subject with 1 terminal deletion - break (b) with displaced fragment (f). D. Metaphase of a blood sample from the same subject, exposed to combination of caffeine and UMTS MT EMF for 15 min, with 2 terminal deletions - breaks (b), and 1 achromatic lesion - gap (g).

ing number of induced breaks in all subjects. Both gaps and breaks and the total number of aberrations induced either by UMTS alone or by caffeine alone, were significantly increased in regards to the sham-exposed/control sample of each subject (Table 1, Fig. 1).

The combined effect of caffeine with the three different exposure durations to UMTS MT EMF (5, 15, and $25 \mathrm{~min})$ on the chromosomes of 3 subjects (No. 4-6) in terms of induced chromatid gaps and breaks, is shown in Table 2 and represented graphically in Figure 3. The number of induced chromosomal aberrations (chromatid gaps and breaks) percell increased almost linearly with increasing exposure duration to the MT EMF, compared to caffeine treatment alone, showing that the UMTS EMF exposure effect on human lymphocytes is dose-depended. Figure 4A shows a metaphase of a control/ sham-exposed blood sample from subject No. 4 (male) with all 46 chromosomes intact. This was a representative picture for most metaphases from control samples. Figure $4 \mathrm{~B}$ shows a metaphase of a caffeine alone-treated blood sample from the same subject with 1 achromatic lesion - gap (g). Figure 4C shows a metaphase from the same subject exposed to combination of caffeine and UMTS MT EMF 5 min, with 1 terminal deletion - break (b). Figure 4D shows a metaphase from the same subject exposed to combination of caffeine and UMTS MT EMF 15 min, with one terminal deletion - break (b) with displaced fragment (f), and one achromatic lesion - gap (g). Figure $4 \mathrm{E}$ shows a metaphase from the same subject exposed to combination of caffeine and UMTS MT EMF $25 \mathrm{~min}$, with two terminal deletions - breaks (b), the one with a displaced fragment (f), and one achromatic lesion - gap (g).

\section{Discussion}

It is shown that while a single 15 min exposure of human blood samples to an active 3G (UMTS) mobile phone in "talk" mode at $1 \mathrm{~cm}$ distance from the handset increased chromatid-type aberrations from $100 \%$ up to $275 \%$, the cor- 


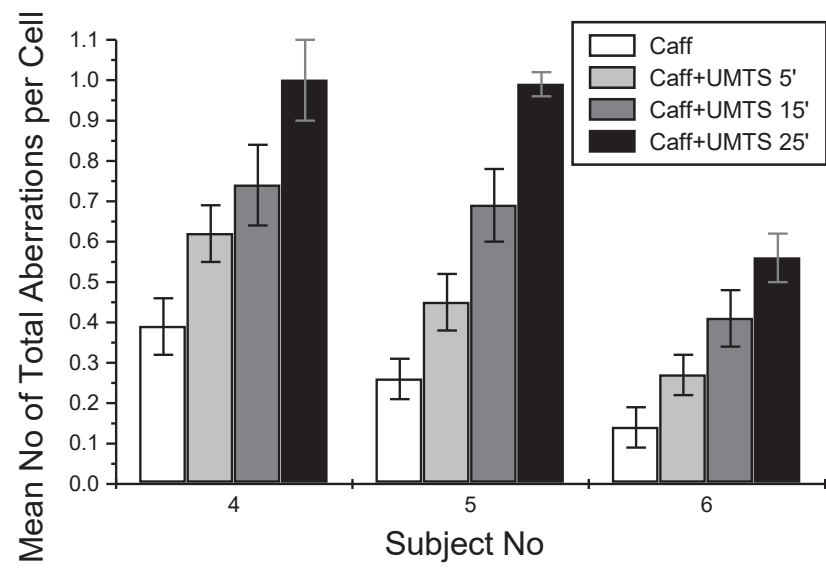

Figure 3. Mean total number of aberrations (gaps and breaks) per cell in 400 cells (peripheral blood lymphocytes) of each group (caffeine treated only, and exposed to combination of caffeine and UMTS for 5, 15, or $25 \mathrm{~min}$ ), for subjects No. 4-6. Data are mean $\pm \mathrm{SD}$

responding increase induced by the high caffeine dose ranged from $89 \%$ up to $250 \%$ (Table 1). Thus, a single MT EMF exposure $\sim 136$ times lower than the newest 2020 ICNIRP exposure limit (or $\sim 34$ times lower than the corresponding 1998 ICNIRP limit), induced chromosomal aberrations in a little higher degree than a caffeine dose $\sim 290$ times higher than the permissible single caffeine dose for an adult human.

This comparison shows that the exposure limits set for microwave EMFs by ICNIRP $(1998 ; 2020)$ are enormously less stringent $(\sim 34 \times 290$ times or $\sim 136 \times 290$ times, respectively) than those for caffeine. Assuming linearity between caffeine dose and MT radiation intensity $\left(\mu \mathrm{W} / \mathrm{cm}^{2}\right)$ regarding their abilities to induce chromatid aberrations and assuming the caffeine single dose limit to be correct (since the effects of caffeine on human organism are fast and evident in contrast to EMF-effects), the ICNIRP (2020) microwave EMF exposure limits averaged over 6 min (short-term) exposures should be lowered by $\sim 40000\left(=4 \times 10^{4}\right)$ times (or the corresponding 1998 ICNIRP limits by $\sim 10^{4}$ times). By lowering the 2020 ICNIRP limit of $4000 \mu \mathrm{W} / \mathrm{cm}^{2}$ (for $2 \mathrm{GHz}$ averaged for $6 \mathrm{~min}$ exposure) by $4 \times 10^{4}$ times (or the 1998 ICNIRP limit by $10^{4}$ times) the limit would become $0.1 \mu \mathrm{W} / \mathrm{cm}^{2}$ for short-term exposures, and by lowering this at least by 100 for long-term exposures it would become $0.001 \mu \mathrm{W} / \mathrm{cm}^{2}$. These limits for short and long exposures would be compatible with the caffeine consumption limit, and realistic according to the EMF-bioeffects literature data (Panagopoulos et al. 2010; Panagopoulos 2011, 2017).

Moreover, the present study showed that when MT EMF exposure is combined with a high caffeine dose, the number of induced chromatid aberrations is dramatically increased compared to the effect of each stressor alone (Table 1, Fig. 1). Even though the caffeine dose used in the experiments was $\sim 290$ times higher than the permissible single dose for an adult individual, this result possibly implies that heavy coffee consumption combined with mobile phone use may significantly increase health risks and should be tested in future experiments. In addition, it shows that the combination of two (or more) separate stressors (called co-stress condition) may have much greater biological effect than the sum of the individual effects of each stressor alone. Since EMF exposure at different bands of the spectrum (RF, ELF, etc.) constitutes a new reality in daily life for everyone, its combination with a variety of other existing stressors (such as development, aging, sickness, infections, ionizing radiation, chemicals, pharmaceuticals, smoking, psychological stress, etc.) should be examined by future studies.

Finally, the present study showed that the effects of MT EMF exposure on humans are dose-dependent and increase

Table 2. Aberrations induced by caffeine and its combination with 3 different exposure durations to UMTS MT EMF 5, 15, 25 min exposure

\begin{tabular}{|c|c|c|c|c|c|c|c|}
\hline $\begin{array}{l}\text { Subject No. } \\
\text { (age, sex) }\end{array}$ & Groups (Samples) & $\begin{array}{l}\text { Gaps in } \\
400 \text { cells }\end{array}$ & $\begin{array}{l}\text { Breaks in } \\
400 \text { cells }\end{array}$ & $\begin{array}{l}\text { Total Aberr. } \\
\text { in } 400 \text { cells }\end{array}$ & $\begin{array}{l}\text { Mean Total Aberr. } \\
\text { per cell } \pm \text { SD }\end{array}$ & $\begin{array}{l}\text { Deviation from } \\
\text { Caff }(\%)\end{array}$ & $p$-value \\
\hline \multirow{4}{*}{$\begin{array}{c}4 \\
(40, \text { Male })\end{array}$} & Caff & 97 & 61 & 158 & $0.39 \pm 0.07$ & & \\
\hline & Caff+UMTS 5 min & 153 & 97 & 250 & $0.62 \pm 0.07$ & +59 & $<0.01$ \\
\hline & Caff+UMTS 15 min & 190 & 106 & 296 & $0.74 \pm 0.10$ & +90 & $<0.01$ \\
\hline & Caff+UMTS $25 \mathrm{~min}$ & 256 & 143 & 399 & $1.00 \pm 0.10$ & +156 & $<0.01$ \\
\hline \multirow{4}{*}{$\begin{array}{c}5 \\
(35, \text { Female })\end{array}$} & Caff & 70 & 34 & 104 & $0.26 \pm 0.05$ & & \\
\hline & Caff+UMTS 5 min & 125 & 55 & 180 & $0.45 \pm 0.07$ & +73 & $<0.01$ \\
\hline & Caff+UMTS 15 min & 217 & 59 & 276 & $0.69 \pm 0.09$ & +165 & $<0.01$ \\
\hline & Caff+UMTS 25 min & 291 & 105 & 396 & $0.99 \pm 0.03$ & +281 & $<0.01$ \\
\hline \multirow{4}{*}{$\begin{array}{c}6 \\
(30, \text { Male })\end{array}$} & Caff & 47 & 8 & 55 & $0.14 \pm 0.05$ & & \\
\hline & Caff+UMTS 5 min & 78 & 30 & 108 & $0.27 \pm 0.05$ & +93 & $<0.01$ \\
\hline & Caff+UMTS 15 min & 124 & 39 & 163 & $0.41 \pm 0.07$ & +193 & $<0.01$ \\
\hline & Caff+UMTS $25 \mathrm{~min}$ & 164 & 60 & 224 & $0.56 \pm 0.06$ & +300 & $<0.01$ \\
\hline
\end{tabular}

Aberr.: aberrations; Caff: caffeine. 
almost linearly with exposure duration. This is in agreement with El-Abd and Eltoweissy (2012), as well as with previous results of my group regarding $2 \mathrm{G}$ MT EMF exposures on fruit fly reproduction and DNA damage on reproductive cells (Panagopoulos and Margaritis 2010; Panagopoulos 2011, 2017).

The present study employed a high caffeine dose ( $~ 290$ times higher than the permissible dose for an adult human). One reason was that this dose is frequently used in lymphocyte experiments to abrogate the $\mathrm{G}_{2}$ checkpoint and study the effect of other stressors such as ionizing radiation on unprotected cells (Pantelias and Terzoudi 2011; Hatzi et al. 2015). Another reason was that preliminary experiments showed that this high caffeine dose induces a comparable effect with that of a few min UMTS exposure. Certainly this is not a representative dose for coffee consumption as shown in the study (see section Caffeine dose evaluation). Future experiments should be conducted combining MT EMF exposure with different caffeine doses $(\leq 300$ times smaller) representative of coffee consumption.

In previous studies of my group, $2 \mathrm{G}$ (GSM) mobile phone radiation exposure on fruit flies induced extensive DNA
A

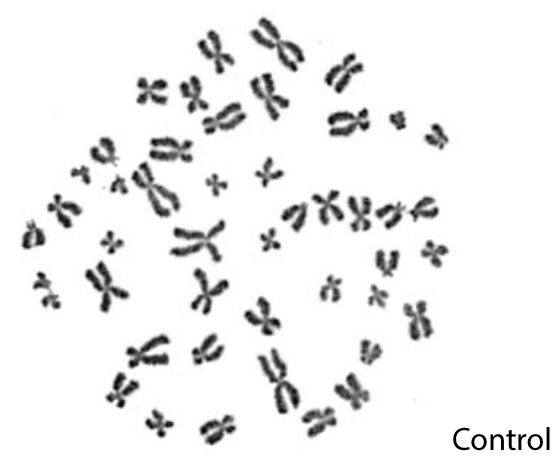

C

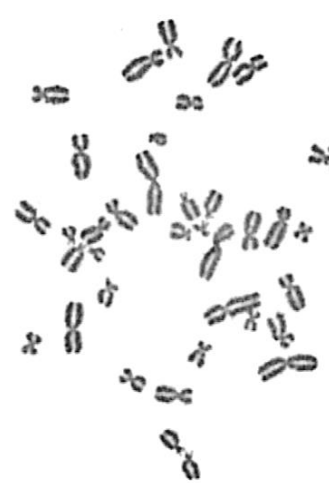

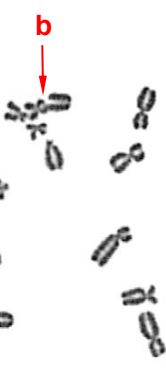

- Caff+UMTS 5

E

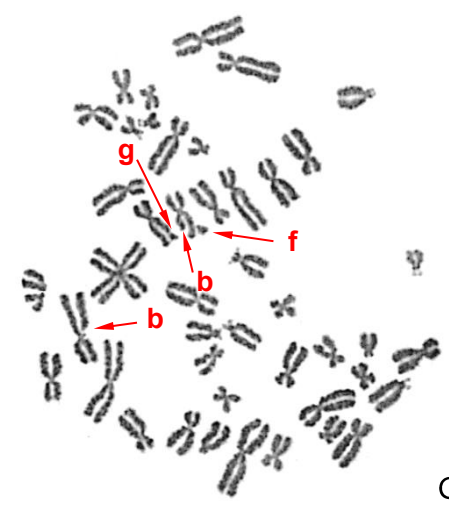

Caff+UMTS 25
B
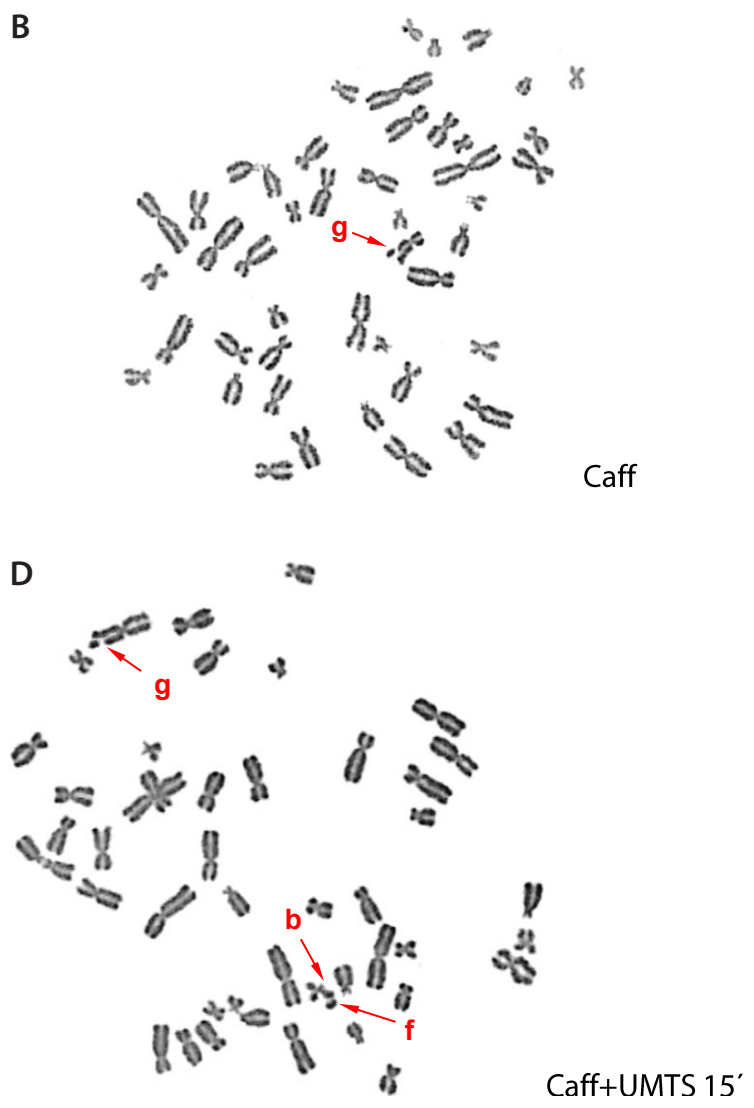

Figure 4. A. Metaphase of Control blood sample from subject No. 4 (male). All 46 chromosomes are intact. B. Metaphase of caffeinetreated blood sample from the same subject with 1 achromatic lesion - gap (g). C. Metaphase of a blood sample from the same subject, exposed to combination of caffeine and UMTS MT EMF for $5 \mathrm{~min}$, with 1 terminal deletion - break (b). D. Metaphase of a blood sample from the same subject, exposed to combination of caffeine and UMTS MT EMF for 15 min, with 1 terminal deletion - break (b) with displaced fragment (f), and 1 achromatic lesion - gap (g). E. Metaphase of a blood sample from the same subject, exposed to combination of caffeine and UMTS MT EMF for $25 \mathrm{~min}$, with 2 terminal deletions - breaks (b), the one with a displaced fragment (f), and 1 achromatic lesion - gap (g). 
damage in the gametes leading to cell death and reproductive decline (Panagopoulos et al. 2007, 2010; Chavdoula et al. 2010; Panagopoulos 2012). Since DNA damage is converted into chromosomal damage during the early $\mathrm{M}$ phase of the cell division cycle (Terzoudi and Pantelias 2006; Pantelias and Terzoudi 2010; Terzoudi et al. 2011; Tian et al. 2018), the recorded chromosomal damage induced by the UMTS (3G) MT EMF and/or caffeine is apparently due to DNA damage caused by these stressors.

The DNA damage recorded in our previous studies was induced only by a few min daily exposures for a few days for radiation intensities down to $1 \mu \mathrm{W} / \mathrm{cm}^{2}$ (Panagopoulos et al. 2010). Setting a short-term exposure limit based on this result, that would reasonably be $0.1 \mu \mathrm{W} / \mathrm{cm}^{2}$, which is the same with the corresponding limit deduced from the results of the present study.

The recorded effects on human peripheral blood lymphocytes are therefore in complete agreement with previous results of my group (Panagopoulos et al. 2007; 2010; Chavdoula et al. 2010; Panagopoulos 2012, 2017, 2019b) showing once more that digital MT microwave EMFs are very genotoxic/bioactive, able to induce DNA damage and consequent chromosome damage in the human cells as well as in other animals. This should be anticipated since cells are essentially the same in all animals, and all biological/ health effects are initiated at the cellular level (Panagopoulos 2019b). It is important to note that the present study based on in vitro exposure of human blood cells implies the same limits for short-term exposures $\left(0.1 \mu \mathrm{W} / \mathrm{cm}^{2}\right)$ and long-term exposures $\left(0.001 \mu \mathrm{W} / \mathrm{cm}^{2}\right)$ to MT EMFs as the previous studies of my group based on in vivo animal exposures.

The main type of aberrations induced by either MT EMF exposure or caffeine or the combination of the two stressors were chromatid gaps (achromatic lesions). While chromatid breaks are more intense damages and easier to be recognized (Conger 1967), both gaps and breaks are damages of the same nature and gaps are actually incomplete breaks (Brecher 1977). Ignoring the gaps and counting only the breaks, may be another reason why certain previous studies, e.g. Stronati et al. (2006), did not find aberrations in human blood lymphocytes, in addition to exposing during more resistant cell conditions (e.g. during the $\mathrm{G}_{0}$ phase instead of during the cell division cycle and especially its most sensitive phases $M$, $\mathrm{G}_{2}$ ), and to employing simulated MT signals.

The recorded chromatid-type aberrations induced by the MT EMF exposure is a non-thermal effect since it was not accompanied by any significant temperature increase of the exposed blood samples. The $0.2^{\circ} \mathrm{C}$ highest temperature increase during the 25 min exposures is well tolerated by the blood cells as previously explained (Panagopoulos 2019a). The upcoming $5 \mathrm{G}$ technology with significantly higher carrier frequencies up to $100 \mathrm{GHz}$, much denser antenna networks, and more intense and collimated radiation beams, is expected to induce significant thermal effects in addition to the non-thermal ones which may not be tolerated by the human/animal body (Singh et al. 2017; Neufeld and Kuster 2018; Thielens et al. 2018, 2020; Panagopoulos 2019a; Hardell and Carlberg 2020). This may represent a great danger for public health which the health authorities should carefully investigate before allowing $5 \mathrm{G}$ installation.

It is shown that real-life MT EMFs emitted by commercially available mobile phone devices or base antennas/cell towers are far more bioactive than simulated corresponding signals with invariable parameters emitted by generators ( $\mathrm{Pa}-$ nagopoulos et al. 2015a; Panagopoulos 2017, 2019b; Kostoff et al. 2020). This is probably one reason why in some of the previous studies no effects of simulated MT EMFs on human lymphocytes were reported (Zeni et al. 2003, 2012; Stronati et al. 2006; Schwarz et al. 2008), while in the present study in which a real UMTS exposure was employed, a very intense effect was found (up to $275 \%$ increase in chromatid aberrations in regards to the control samples). From the five previous studies with human lymphocytes exposed to real-life MT EMFs (Ji et al. 2004; Gulati et al. 2016; Danese et al. 2017; Zothansiama et al. 2017; Panagopoulos 2019a), four found effects (Ji et al. 2004; Gulati et al. 2016; Zothansiama et al. 2017; Panagopoulos 2019a) in agreement with the majority of lymphocyte studies, while one (Danese et al. 2017) did not. This is the only study found employing real-life MT exposure that reported no effect on human lymphocytes, and one of the very few on any biological model (Panagopoulos 2017, $2019 b)$. In this study, in addition to other issues discussed in the introduction, they exposed the cells during their resting $\mathrm{G}_{0}$ phase, alike Stronati et al. (2006), instead of exposing them during the cell division cycle, and especially the most sensitive phases $M, G_{2}$ (Nias 1998; Terzoudi et al. 2011).

The study that found real-life UMTS (3G) exposure to be even more genotoxic than real-life GSM (2G) (D'Silva et al. 2017 ) is in line with the fact that newer types of MT EMFs (3G, 4G, etc) transmit increasingly higher amount/density of variable information (speech, text, images, video, Internet) making the signal increasingly complicated, unpredictably varying each moment, and increasingly more bioactive due to the inability of living organisms to adapt. Thus, the effects of the upcoming 5G MT EMF are expected to be even more intense than those of $2 \mathrm{G}, 3 \mathrm{G}, 4 \mathrm{G}$. This should be seriously considered by the responsible public health authorities.

Since the health effects of all microwave telecommunication EMFs (including MT, Wi-Fi, domestic cordless phones, Bluetooth wireless connections etc.) are of utmost importance in our days, studies should be conducted to test the most sensitive biological conditions with real-life exposures, and in combination with other environmental stressors, otherwise the results may be misleading in terms of public health protection. Exposures by any type of simulated signals and within any type of exposure chambers used to produce 
"uniform" exposures such as "reverberation chambers" or "TEM chambers" (Ardoino et al. 2005; Wu et al. 2009) do not represent real-life exposure conditions and may produce misleading outcomes towards "no effect" findings (Panagopoulos 2017, 2019b; Pall 2018).

The disruption of cell electrochemical balance by manmade (polarized) EMFs through irregular gating of voltagegated ion channels on cell membranes is described by the "ion forced-oscillation mechanism" (Panagopoulos et al. 2000, 2002, 2015b, 2020). This may lead to DNA damage by intracellular release of free radicals or hydrolytic enzymes like DNases (Barzilai and Yamamoto 2004; Phillips et al. 2009; Panagopoulos 2011; Pall 2013; Yakymenko et al. 2016). This is in line with the attribution of the DNA and chromosome damage to oxidative stress by El Abd and Eltoweissy (2012). What is referred to by Pall (2018) as voltage-gated calcium channel mechanism ("VGCC mechanism") is the application of the above mechanism specifically on the calcium voltage-gated ion channels. The same mechanism refers to all cation voltage-gated channels, and calcium - although more extensively studied - should not be considered more important than other cations.

Acknowledgements. I thank Drs G. Pantelias, G. Terzoudi, M. Karakosta, and V. Hatzi, for the laboratory techniques with the human lymphocytes. I also thank the laboratory staff members A. Vasilaki and K. Barszczewska for laboratory assistance and help with the blind scoring. Finally, I thank physician D. Ampelas and chemist G. Limnioti for providing information on caffeine dissolution in the blood and checking my calculations on caffeine dose evaluation. The study was supported by the Special Account for Research Grants of the National and Kapodistrian University of Athens.

Conflict of interest. The author declares no actual or potential competing financial interests.

\section{References}

Ardoino L, Lopresto V, Mancini S, Marino C, Pinto R, Lovisolo GA (2005): A radiofrequency system for in vivo pilot experiments aimed at the studies on biological effects of electromagnetic fields. Phys. Med. Biol. 50, 3643-3654 https://doi.org/10.1088/0031-9155/50/15/011

Baan R, Grosse Y, Lauby Secretan B, El Ghissassi F, Bouvard V, Benbrahim Tallaa L, Guha N, Islami F, Galichet L, Straif K (2011): WHO International Agency for Research on Cancer Monograph Working Group: Carcinogenicity of radiofrequency electro $\neg$ magnetic fields. Lancet Oncol. 12, 624626 https://doi.org/10.1016/S1470-2045(11)70147-4

Baohong W, Jiliang H, Lifen J, Deqiang L, Wei Z, Jianlin L, Hongping D (2005): Studying the synergistic damage effects induced by $1.8 \mathrm{GHz}$ radiofrequency field radiation (RFR) with four chemical mutagens on human lymphocyte DNA using comet assay in vitro. Mutat. Res. 578, 149-157 https://doi.org/10.1016/j.mrfmmm.2005.05.001
Baohong W, Lifen J, Lanjuan L, Jianlin L, Deqiang L, Wei Z, Jiliang $H$ (2007): Evaluating the combinative effects on human lymphocyte DNA damage induced by ultraviolet ray $\mathrm{C}$ plus $1.8 \mathrm{GHz}$ microwaves using comet assay in vitro. Toxicology 232, 311-316 https://doi.org/10.1016/j.tox.2007.01.019

Barzilai A, Yamamoto K (2004): DNA damage responses to oxidative stress (Review). DNA Repair 3, 1109-1115 https://doi.org/10.1016/j.dnarep.2004.03.002

Belyaev IY, Hillert L, Protopopova M, Tamm C, Malmgren LO, Persson BR, Selivanova G, Harms-Ringdahl M (2005): $915 \mathrm{MHz}$ microwaves and $50 \mathrm{~Hz}$ magnetic field affect chromatin conformation and 53BP1 foci in human lymphocytes from hypersensitive and healthy persons. Bioelectromagnetics 26, 173-184 https://doi.org/10.1002/bem.20103

Belyaev IY, Markovà E, Hillert L, Malmgren LOG, Persson BRR (2009): Microwaves from UMTS/GSM mobile phones induce long-lasting inhibition of 53BP $1 / \gamma-\mathrm{H} 2 \mathrm{AX}$ DNA repair foci in human lymphocytes. Bioelectromagnetics 30, 129-141 https://doi.org/10.1002/bem.20445

Brecher S, (1977): Ultra-structural observations of x-ray induced chromatid gaps. Mutat. Res. 42, 249-268 https://doi.org/10.1016/S0027-5107(77)80028-6

Carlberg M, Hardell L (2017): Evaluation of mobile phone and cordless phone use and glioma risk using the Bradford Hill viewpoints form 1965 on association or causation. Bio. Med. Res. Int. 2017, 9218486 https://doi.org/10.1155/2017/9218486

Chavdoula ED, Panagopoulos DJ, Margaritis LH (2010): Comparison of biological effects between continuous and intermittent exposure to GSM-900 MHz mobile phone radiation. Detection of apoptotic cell death features. Mutat. Res. 700, 51-61 https://doi.org/10.1016/j.mrgentox.2010.05.008

Conger AD (1967): Real chromatid deletions versus gaps. Mutat. Res. 4, 449-459 https://doi.org/10.1016/0027-5107(67)90007-3

Cook DG, Peacock JL, Feyerabend C, Carey IM, Jarvis MJ, Anderson HR, Bland JM (1996): Relation of caffeine intake and blood caffeine concentrations during pregnancy to fetal growth: prospective population based study. BMJ 313, 1358-1362 https://doi.org/10.1136/bmj.313.7069.1358

Danese E, Lippi G, Buonocore R, Benati M, Bovo C, Bonaguri C, Salvagno GL, Brocco G, Roggenbuck, Montagnana M (2017): Mobile phone radiofrequency exposure has no effect on DNA double strand breaks (DSB) in human lymphocytes. Ann. Transl. Med. 5, 272 https://doi.org/10.21037/atm.2017.04.35

D'Silva MH, Swer RT, Anbalagan J, Rajesh B. (2017): Effect of radiofrequency radiation emitted from $2 \mathrm{G}$ and $3 \mathrm{G}$ cell phone on developing liver of chick embryo - a comparative study. J. Clin. Diagn. Res. 11, 5-9 https://doi.org/10.7860/JCDR/2017/26360.10275

EFSA (European Food Safety Authority) (2015): Scientific opinion on the safety of caffeine. EFSA Journal 13, 4102 https://doi.org/10.2903/j.efsa.2015.4102

El-Abd SF, Eltoweissy MY (2012): Cytogenetic alterations in human lymphocyte culture following exposure to radiofrequency field of mobile phone. J. Appl. Pharm. Sci. 2, 16-20 
Falcioni L, Bua L, Tibaldi E, Lauriola M, De Angelis L, Gnudi F, Mandrioli D, Manservigi M, Manservisi F, Manzoli I, et al. (2018): Report of final results regarding brain and heart tumors in Sprague-Dawley rats exposed from prenatal life until natural death to mobile phone radiofrequency field representative of a $1.8 \mathrm{GHz}$ GSM base station environmental emission. Environ. Res. 165, 496-503 https://doi.org/10.1016/j.envres.2018.01.037

Gulati S, Yadav A, Kumar N, Kanupriya, Aggarwal NK, Kumar R, Gupta R (2016): Effect of GSTM1 and GSTT1 polymorphisms on genetic damage in humans populations exposed to radiation from mobile towers. Arch. Environ. Contam. Toxicol. 70, 615-625 https://doi.org/10.1007/s00244-015-0195-y

Hardell L, Carlberg M, Hansson Mild K (2013): Use of mobile phones and cordless phones is associated with increased risk for glioma and acoustic neuroma. Pathophysiology 20, $85-110$ https://doi.org/10.1016/j.pathophys.2012.11.001

Hardell L (2017): World Health Organization, radiofrequency radiation and health - a hard nut to crack (Review). Int. J. Oncol. 51, 405-413 https://doi.org/10.3892/ijo.2017.4046

Hardell L (2019): Notes on parliament hearing in Tallinn, Estonia June 4, 2019 as regards the deployment of the fifth generation, $5 \mathrm{G}$, of wireless communication. World Acad. Sci. J. 1, 275-282 https://doi.org/10.3892/wasj.2019.28

Hardell L, Nyberg R (2020): Appeals that matter or not on a moratorium on the deployment of the fifth generation, $5 \mathrm{G}$, for microwave radiation. Mol. Clin. Oncol. 12, 247-257 https://doi.org/10.3892/mco.2020.1984

Hardell L, Carlberg M (2020): Health risks from radiofrequency radiation, including $5 \mathrm{G}$, should be assessed by experts with no conflicts of interest. Oncol. Lett. 20, 15 https://doi.org/10.3892/ol.2020.11876

Hatzi VI, Karakosta M, Barszczewska K, Karachristou I, Pantelias G, Terzoudi GI (2015): Low concentrations of caffeine induce asymmetric cell division as observed in vitro by means of the CBMN-assay and iFISH. Mutat. Res. Genet. Toxicol. Environ. Mutagen 793, 71-78

https://doi.org/10.1016/j.mrgentox.2015.08.002

Higdon JV, Frei B (2006): Coffee and health: a review of recent human research, critical reviews in food science and nutrition. Crit. Rev. Food Sci. Nutr. 46, 101-123 https://doi.org/10.1080/10408390500400009

IAEA (2011): Cytogenetic Dosimetry: Applications in Preparedness for and Response to Radiation Emergencies, International Atomic Energy Agency

IARC (1991): Coffee, Tea, Mate, Methylxanthines, and Methylglyoxal. Vol. 51, International Agency for Research on Cancer, World Health Organization

IARC (2002): Non-Ionizing Radiation. Part 1: Static and Extremely Low-Frequency (ELF) Electric and Magnetic Fields. Vol. 80, International Agency for Research on Cancer, World Health Organization

IARC (2013): Non-Ionizing Radiation. Part 2: Radiofrequency Electromagnetic Fields. Vol. 102, International Agency for Research on Cancer, World Health Organization
IARC (2016): Coffee, Mate and Very Hot Beverages. Vol. 116, International Agency for Research on Cancer, World Health Organization

ICNIRP (1998): Guidelines for limiting exposure to time-varying electric, magnetic and electromagnetic fields (up to $300 \mathrm{GHz}$ ). Health Phys. 74, 494-522

ICNIRP (2020): Guidelines for limiting exposure to electromagnetic fields (100 kHz to 300GHz). Health Phys. 118, 483-524 https://doi.org/10.1097/HP.0000000000001210

Ji S, Oh E, Sul D, Choi JW, Park H, Lee E (2004): DNA damage of lymphocytes in volunteers after 4 hours use of mobile phone. J. Prev. Med. Public Health 37, 373-380

Kostoff RN, Heroux P, Aschner M, Tsatsakis A (2020): Adverse health effects of $5 \mathrm{G}$ mobile networking technology under reallife conditions. Toxicol. Lett. 323, 35-40 https://doi.org/10.1016/j.toxlet.2020.01.020

Kuhlmann W, Fromme HG, Heege EM, Ostertag W (1968): The mutagenic action of caffeine in higher organisms (Review). Cancer Res. 28, 2375-2389

Manti L, Braselmann H, Calabrese ML, Massa R, Pugliese M, Scampoli P, Sicignano G, Grossi G (2008): Effects of modulated microwave radiation at cellular telephone frequency (1.95 $\mathrm{GHz}$ ) on X-ray-induced chromosome aberrations in human lymphocytes in vitro. Radiat. Res. 169, 575-583 https://doi.org/10.1667/RR1044.1

Markova E, Hillert L, Malmgren L, Persson BR, Belyaev IY (2005): Microwaves from GSM mobile telephones affect 53BP1 and gamma-H2AX foci in human lymphocytes from hypersensitive and healthy persons. Environ. Health Perspect. 113, 1172-1177 https://doi.org/10.1289/ehp.7561

McClelland S, Jaboin JJ (2018): The radiation safety of 5G wi-fi: reassuring or Russian roulette? Int. J. Radiat. Oncol. Biol. Phys. 101, 1274-1275 https://doi.org/10.1016/j.ijrobp.2018.04.051

Melnick RL (2019): Commentary on the utility of the National Toxicology Program study on cell phone radiofrequency radiation data for assessing human health risks despite unfounded criticisms aimed at minimizing the findings of adverse health effects. Environ. Res. 168, 1-6 https://doi.org/10.1016/j.envres.2018.09.010

Mendelsohn J, Hudic D, Castagnola J (1981): DNA synthesis and proliferation of human lymphocytes in vitro: Ill. Fate of cycling cells in aging cultures of phytohemagglutinin stimulated human lymphocytes. J. Cell. Physiol. 106, 13-22 https://doi.org/10.1002/jcp.1041060103

Miller AB, Morgan LL, Udasin I, Davis DL (2018): Cancer epidemiology update, following the 2011 IARC evaluation of radiofrequency electromagnetic fields (Monograph 102). Environ. Res. 167, 673-683 https://doi.org/10.1016/j.envres.2018.06.043

Miller AB, Sears ME, Morgan LL, Davis DL, Hardell L, Oremus M, Soskolne CL (2019): Risks to health and well-being from radio-frequency radiation emitted by cell phones and other wireless devices. Front. Public Health 7, 223 https://doi.org/10.3389/fpubh.2019.00223

Neufeld E, Kuster N (2018): Systematic derivation of safety limits for time-varying $5 \mathrm{G}$ radiofrequency exposure based on analytical models and thermal dose. Health Physics 115, 705-711 
https://doi.org/10.1097/HP.0000000000000930

Nias AHW (1998): An Introduction to Radiobiology. John Wiley \& Sons

NTP (National Toxicology Program) (2018): Toxicology and Carcinogenesis Studies in Hsd: Sprague Dawley SD rats exposed to whole-body radio frequency radiation at a frequency (900 MHz) and modulations (GSM and CDMA) used by cell phones. NTP TR 595, Department of Health and Human Services, USA

Pall ML (2013): Electromagnetic fields act via activation of voltagegated calcium channels to produce beneficial or adverse effects. J. Cell. Mol. Med. 17, 958-965 https://doi.org/10.1111/jcmm.12088

Pall ML (2018): Wi-Fi is an important threat to human health. Environ. Res. 164, 405-416 https://doi.org/10.1016/j.envres.2018.01.035

Panagopoulos DJ, Messini N, Karabarbounis A, Filippetis AL, Margaritis LH (2000): A mechanism for action of oscillating electric fields on cells. Biochem. Biophys. Res. Comm. 272, 634-640 https://doi.org/10.1006/bbrc.2000.2746

Panagopoulos DJ, Karabarbounis A, Margaritis LH (2002): Mechanism for action of electromagnetic fields on cells. Biochem. Biophys. Res. Commun. 298, 95-102 https://doi.org/10.1016/S0006-291X(02)02393-8

Panagopoulos DJ, Chavdoula ED, Nezis IP, Margaritis LH (2007): Cell death induced by GSM $900 \mathrm{MHz}$ and DCS $1800 \mathrm{MHz}$ mobile telephony radiation. Mutat. Res. 626, 69-78 https://doi.org/10.1016/j.mrgentox.2006.08.008

Panagopoulos DJ, Chavdoula ED, Margaritis LH (2010): Bioeffects of mobile telephony radiation in relation to its intensity or distance from the antenna. Int. J. Radiat. Biol. 86, 345-357 https://doi.org/10.3109/09553000903567961

Panagopoulos DJ, Margaritis LH (2010): The effect of exposure duration on the biological activity of mobile telephony radiation. Mutat. Res. 699, 17-22 https://doi.org/10.1016/j.mrgentox.2010.04.010

Panagopoulos DJ (2011): Analyzing the health impacts of modern telecommunications microwaves. In: Advances in Medicine and Biology (Ed. Berhardt LV), Vol. 17, Nova Science Publishers, Inc., New York, USA

Panagopoulos DJ (2012): Effect of microwave exposure on the ovarian development of drosophila melanogaster. Cell Biochem. Biophys. 63, 121-132

https://doi.org/10.1007/s12013-012-9347-0

Panagopoulos DJ, Johansson O, Carlo GL (2015a): Real versus simulated mobile phone exposures in experimental studies. BioMed Res. Int. 2015, 607053 https://doi.org/10.1155/2015/607053

Panagopoulos DJ, Johansson O, Carlo GL (2015b): Polarization: A key difference between man-made and natural electromagnetic fields, in regard to biological activity. Sci. Reports 5, 14914 https://doi.org/10.1038/srep14914

Panagopoulos DJ (2017): Mobile telephony radiation effects on insect ovarian cells. The necessity for real exposures bioactivity assessment. The key role of polarization, and the ion forcedoscillation mechanism. In: Microwave Effects on DNA and Proteins (Ed. Geddes CD), Springer https://doi.org/10.1007/978-3-319-50289-2_9

Panagopoulos DJ, Chrousos GP (2019): Shielding methods and products against man-made electromagnetic fields: protection versus risk. Sci. Total. Environ. 667C, 255-262 https://doi.org/10.1016/j.scitotenv.2019.02.344

Panagopoulos DJ (2019a): Chromosome damage in human cells induced by UMTS mobile telephony radiation. Gen. Physiol. Biophys. 38, 445-454 https://doi.org/10.4149/gpb_2019032

Panagopoulos DJ (2019b): Comparing DNA damage induced by mobile telephony and other types of man-made electromagnetic fields (Review). Mutat. Res. 781, 53-62 https://doi.org/10.1016/j.mrrev.2019.03.003

Panagopoulos DJ, Balmori A, Chrousos GP (2020): On the biophysical mechanism of sensing upcoming earthquakes by animals. Sci. Total. Environ. 717, 136989 https://doi.org/10.1016/j.scitotenv.2020.136989

Pantelias GE, Terzoudi GI (2010): Functional cell-cycle chromatin conformation changes in the presence of DNA damage result into chromatid breaks. A new insight in the formation of radiation-induced chromosomal aberrations based on the direct observation of interphase chromatin. Mutat. Res. 701, 27-37 https://doi.org/10.1016/j.mrgentox.2010.04.006

Pantelias GE, Terzoudi GI (2011): A standardized G2-assay for the prediction of individual radiosensitivity. Radiother. Oncol. 101, 28-34 https://doi.org/10.1016/j.radonc.2011.09.021

Phillips JL, Singh NP, Lai H (2009): Electromagnetic fields and DNA damage. Pathophysiology 16, 79-88 https://doi.org/10.1016/j.pathophys.2008.11.005

Pincheira J, López-Sáez JF (1991): Effects of caffeine and cycloheximide during G2 prophase in control and X-ray-irradiated human lymphocytes. Mutat. Res. 251, 71-77 https://doi.org/10.1016/0027-5107(91)90216-B

Sauter M (2011): From GSM to LTE: An introduction to mobile networks and mobile broadband. John Wiley \& Sons https://doi.org/10.1002/9780470978238

Schwarz C, Kratochvil E, Pilger A, Kuster N, Adlkofer F, Ruediger HW (2008): Radiofrequency electromagnetic fields (UMTS, $1,950 \mathrm{MHz}$ ) induce genotoxic effects in vitro in human fibroblasts but not in lymphocytes. Int. Arch. Occup. Environ. Health 81, 755-767 https://doi.org/10.1007/s00420-008-0305-5

Singh RK, Bisht D, Prasad RC (2017): Development of 5G mobile network technology and its architecture. IJRTER 3, 196-201 https://doi.org/10.23883/IJRTER.2017.3475.VMOF0

Smith-Roe SL, Wyde ME, Stout MD, Winters JW, Hobbs CA, Shepard KG, Green AS, Kissling GE, Shockley KR, Tice RR, et al. (2020): Evaluation of the genotoxicity of cell phone radiofrequency radiation in male and female rats and mice following subchronic exposure. Environ. Mol. Mutagen. 1, 276-290 https://doi.org/10.1002/em.22343

Stronati L, Testa A, Moquet J, Edwards A, Cordelli E, Villani P, Marino C, Fresegna AM, Appolloni M, Lloyd D (2006): $935 \mathrm{MHz}$ cellular phone radiation. An in vitro study of genotoxicity in human lymphocytes. Int. J. Radiat. Biol. 82, 339-346 
https://doi.org/10.1080/09553000600739173

Terzoudi GI, Pantelias GE (2006): Cytogenetic methods for biodosimetry and risk individualization after exposure to ionizing radiation. Radiat. Prot. Dosimetry 122, 513-520 https://doi.org/10.1093/rpd/ncl509

Terzoudi GI, Hatzi VI, Donta-Bakoyianni C, Pantelias GE (2011): Chromatin dynamics during cell cycle mediate conversion of DNA damage into chromatid breaks and affect formation of chromosomal aberrations: biological and clinical significance. Mutat. Res. 711, 174-186 https://doi.org/10.1016/j.mrfmmm.2010.12.011

Thielens A, Bell D, Mortimore DB, Greco MK, Martens L, Joseph W (2018): Exposure of insects to radio-frequency electromagnetic fields from 2 to $120 \mathrm{GHz}$. Sci. Reports 8, 3924 https://doi.org/10.1038/s41598-018-22271-3

Thielens A, Greco MK, Verloock L, Martens L, Joseph W (2020): Radio-frequency electromagnetic field exposure of western honey bees. Sci. Reports 10, 461 https://doi.org/10.1038/s41598-019-56948-0

Tian XL, Lu X, Feng JB, Cai TJ, Li S, Tian M, Liu QJ (2018): Alterations in histone acetylation following exposure to $60 \mathrm{Co}$ $\gamma$-rays and their relationship with chromosome damage in human lymphoblastoid cells. Radiat. Environ. Biophys. 57, 215-222 https://doi.org/10.1007/s00411-018-0742-9

Wever R (1979): The Circadian System of Man: Results of Experiments under Temporal Isolation. Springer-Verlag

Wu GW, Liu XX, Wu MX, Zhao JY, Chen WL, Lin RH, Lin JM (2009): Experimental study of millimeter wave-induced dif- ferentiation of bone marrow mesenchymal stem cells into chondrocytes. Int. J. Mol. Med. 23, 461-467 https://doi.org/10.3892/ijmm_00000152

Yakymenko I, Tsybulin O, Sidorik E, Henshel D, Kyrylenko O, Kyrylenko S (2016): Oxidative mechanisms of biological activity of low-intensity radiofrequency radiation. Electromagn. Biol. Med. 35, 186-202 https://doi.org/10.3109/15368378.2015.1043557

Zeni O, Chiavoni AS, Sannino A, Antolini A, Forigo D, Bersani F, Scarfi MR (2003): Lack of genotoxic effects (micronucleus induction) in human lymphocytes exposed in vitro to $900 \mathrm{MHz}$ electromagnetic fields. Radiat. Res. 160, 152-158 https://doi.org/10.1667/RR3014

Zeni O, Sannino A, Romeo S, Massa R, Sarti M, Reddy AB, Prihoda TJ, Vijaya-laxmi, Scarfi MR (2012): Induction of an adaptive response in human blood lymphocytes exposed to radiofrequency fields: influence of the universal mobile telecommunication system (UMTS) signal and the specific absorption rate. Mutat. Res. 747, 29-35 https://doi.org/10.1016/j.mrgentox.2012.03.013

Zothansiama, Zosangzuali M, Lalramdinpuii M, Jagetia GC (2017): Impact of radiofrequency radiation on DNA damage and antioxidants in peripheral blood lymphocytes of humans residing in the vicinity of mobile phone base stations. Electromagn. Biol. Med. 36, 295-305

https://doi.org/10.1080/15368378.2017.1350584

Received: August 4, 2020

Final version accepted: September 2, 2020 